\title{
CUSTOMER PREFERENCE TOWARDS E-BANKING SERVICES IN PUBLIC SECTOR AND PRIVATE SECTOR BANKS IN COIMBATORE CITY
}

\section{RAVEENDHAR ${ }^{1} \&$ T SAMSAI ${ }^{2}$}

${ }^{1} P G$ Scholar, Department of agricultural and rural management, Tamil Nadu Agricultural University, Coimbatore, Tamil Nadu, India

${ }_{2}^{2}$ Assistant Professor, Department of agricultural and rural management, Tamil Nadu Agricultural University, Coimbatore,

Tamil Nadu, India

\begin{abstract}
In the present scenario, internet has changed the life of many people, and it has become a powerful tool for communication and marketing. The purpose of the study is to find out the most preferred e-banking service, the factors influencing their preferences in E-banking services, and the problem faced by the respondents and to suggest suitable strategies for the improvement of E-banking services. The study was done in Coimbatore city comprising a sample size of 80 , in which 40 sample respondents were public sector and 40 sample respondents' private sector banks. The methodology adopted were percentage analysis, important performance analysis and Garrett ranking. By using purposive sampling, the data were collected from interview schedule. The customers are more aware about the e-banking service but they lack knowledge in operating. Usage of e-banking service is high because more banking services are easy and can access from anywhere. This study also analysed the factors that influence them to prefer E-banking and also got the suggestions for improving the e-banking services.

KEYWORDS: E-banking services, public sector and private sector banks, most preferred, factor influencing, problem and suggestions
\end{abstract}

Received: Nov 18, 2020; Accepted: Dec 09, 2020; Published: Dec 26, 2020; Paper Id.: IJESRDEC20202

\section{INTRODUCTION}

\section{E-banking}

The term electronic banking refers to banking services through electronic such as automatic teller machine, internet banking, telephone banking, debit and credit cards and other electric devices. By using electronic bank customer need not visit bank for financial transactions. Now day more customer were highly using internet so the bank used the internet as medium to access various types of financial transactions. The first bank introduced electronic bank services by ICICI bank in the year 1996. This electronic bank services help the customer to access various type of financial transaction, saves time of customer works and financial transaction can be done with internet medium from anywhere.

\section{Internet Banking}

Internet banking services can be done using the bank website from anywhere and anytime. Username, one time passwords and passwords were securities of internet banking. By using this services we can do fund transfer, bill payment, balance enquiries etc. 


\section{Mobile Banking}

Mobile banking services can be done using mobile application by mobile device. In which many financial transaction services can be done through mobile and cellular devices. Username, MPIN and TPIN, password and One-time passwords, were securities of mobile banking.

\section{ATM}

It is electronic computerized telecommunication devices which is used to access financial transaction such as fund transfer, cash withdraw, cash deposits, balance enquiry, etc. PIN and account number were securities of ATM. ATM is called as automatic teller machine.

\section{Credit Card}

Credit card is used to borrow value of money from the bank with limitation. Credit card is also known as buy product now and pay it later. PIN is the surety of credit card.

\section{Debit Card}

It is small chipped card which is used to buy a product with your money already credit in your account and it is used to purchase in online shopping. It is also used for some financial transaction such balance enquiry, cash withdraw, etc. PIN is the security of debit card.

\section{OBJECTIVE}

- To measure the customer preference towards E-banking services provided by public sector and private sector banks in Coimbatore

- To identify the factors influencing customer preference in E-banking services

- To examine the problem faced by the respondents in E-banking services

- To suggest suitable strategies for the improvement of E-banking service

\section{Materials and Methods}

This study is intended to know the most preferred, factor influencing and problem faced by customer towards e-banking services in Coimbatore district. Primary data has been collected from public sector and private sector banks. total sample respondent is 80 in which 40 sample from public sector banks (state bank of India, Canara bank and Indian bank)and 40 sample from private sector banks (ICICI bank, Axis bank and KVB bank).data were analysed with percentage analysis, Henry Garrett Ranking Technique and important performance Analysis

DATA ANALYSIS AND INTERPRETATION:

Table 1: Demographic Details of Sample Respondents

\begin{tabular}{|c|c|c|c|}
\hline \multirow{2}{*}{ Characteristics } & Category & $\begin{array}{c}\text { Number Of Sample } \\
\text { Respondent } \\
(\mathbf{N}=\mathbf{1 0 0})\end{array}$ & $\begin{array}{c}\text { Percentage To } \\
\text { Total }\end{array}$ \\
\hline \multirow{2}{*}{ Gender } & Male & 66 & 82.5 \\
\cline { 2 - 4 } & Female & 14 & 17.5 \\
\hline Total & & 80 & 100 \\
\hline
\end{tabular}




\begin{tabular}{|c|c|c|c|}
\hline \multirow{5}{*}{ Age (In years)* } & up to 20 & 10 & 12.5 \\
\hline & $21-30$ & 31 & 38.8 \\
\hline & $31-40$ & 19 & 23.8 \\
\hline & $41-50$ & 14 & 17.5 \\
\hline & $>50$ & 6 & 7.5 \\
\hline Total & & 80 & 100.0 \\
\hline \multirow{6}{*}{ Education } & Illiterate & 8 & 10.0 \\
\hline & Primary & 3 & 3.8 \\
\hline & secondary & 0 & 0 \\
\hline & higher secondary & 22 & 27.5 \\
\hline & Graduate & 46 & 58.8 \\
\hline & post graduate & 1 & 1.2 \\
\hline Total & & 80 & 100 \\
\hline \multirow{6}{*}{ Profession } & private sector & 37 & 46.2 \\
\hline & public sector & 11 & 13.8 \\
\hline & Retired & 0 & 0 \\
\hline & Student & 16 & 20.0 \\
\hline & Business & 12 & 15.0 \\
\hline & no profession & 4 & 5.0 \\
\hline Total & Total & 80 & 100 \\
\hline \multirow{6}{*}{ Income } & up to 20000 & 29 & 36.2 \\
\hline & $20001-30000$ & 11 & 13.7 \\
\hline & $30001-40000$ & 5 & 6.3 \\
\hline & $40001-50000$ & 9 & 11.3 \\
\hline & above 50000 & 6 & 7.5 \\
\hline & Family income & 20 & 25.0 \\
\hline Total & & 80 & 100 \\
\hline
\end{tabular}

It could be inferred from the above Table1,that the respondents were classified based on different demographic features revealed that majority of sample respondent were male 82.5 per cent followed by female 17.5 per cent. The most of sample respondent were under the age category of 21-30 per cent followed by 31-40 per cent. The age category of 41-50, up to 20 and above 50 were 17.5 per cent, 10 per cent and 7.5 per cent respectively.

In education character, majority of sample respondent were gradate 58.8 per cent and followed by high secondary 27.5 per cent. There were 10 per cent illiterate, 3.8 per cent primary and only 1.2 per cent were post graduate. In profession character, majority of sample respondents were private sector 46.2 per cent followed by student of 20 per cent there were 15 per cent of no profession and only 13.8 per cent were public sector .In income character, most of the sample respondent were up to 2000o per month of 36.3 per cent followed by family income of 25 per cent. There were 13.8 per cent of 20001$30000,11.3$ per cent of $40001-50000,7.5$ per cent of above 50000 and only 6.3 per cent were $30001-40000$. 
Table 2: To measure the customer preference towards E-banking services

\begin{tabular}{|l|l|l|l|l|}
\hline \multirow{2}{*}{ E-banking service } & \multicolumn{2}{c|}{ Public sector bank } & \multicolumn{2}{c|}{ Private sector bank } \\
\cline { 2 - 5 } & \multicolumn{1}{|c|}{ Garrett score } & Rank & Garrett score & Rank \\
\hline Debit card & 53.8 & 2 & 60.075 & 1 \\
\hline Internet banking & 42.75 & 3 & 35.05 & 3 \\
\hline Mobile banking & 53.825 & 1 & 46.325 & 2 \\
\hline Credit card & 21.35 & 4 & 26.475 & 4 \\
\hline
\end{tabular}

From the above table, it could be inferred that majority of sample respondents mostly preferred mobile banking in public sector bank and debit card in private sector bank according to the analysis of Garrett's ranking technique.

\section{To identify the factors influencing customer preference in E-banking services}

Expectation and satisfaction analysis based on the important performance analysis

\section{Important Performance Analysis}

Importance-Performance Analysis (IPA) are a neighbourhood of selling research techniques that involve the analysis of customer attitudes toward main product or service and has been applied in several markets: e.g., education, health care, hospitality industry, tourism, among others ("e.g., Sethna, 1982; Hawes \& Rao, 1985; Cunningham \& Gaeth, 1989; Dolinsky, 1991; Martilla \& James, 1977; Alexitch et al. 2004; Kitcharoen, 2004; Go \& Zhang, 2008; Silva \& Fernandes, 2010").

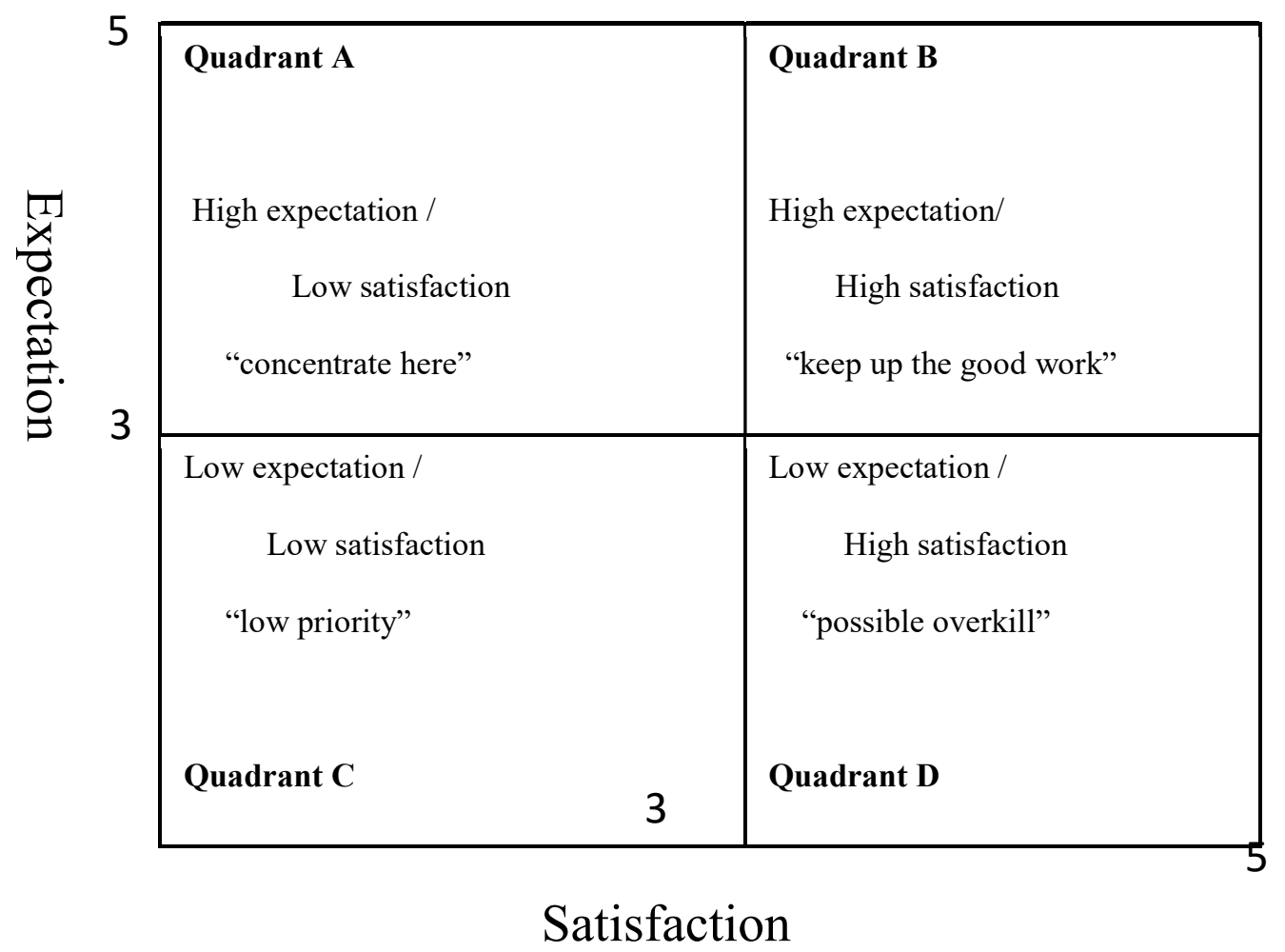


The four quadrants in importance-performance analysis are characterized as (Martilla \& James, 1977, p. 78):

-“Quadrant A. "Concentrate here”- high expectation, low satisfaction: requires immediate attention for improvement and are major weaknesses";

-“Quadrant B. "Keep up with the good work" - high expectation, high satisfaction: indicate opportunities for achieving or maintaining competitive advantage and are major strengths";

-“Quadrant C. "Low priority" - low expectation, low satisfaction: are minor weaknesses and do not require additional effort";

-“Quadrant D. "Possible overkill' - low expectation, high satisfaction: indicate that business resources committed to those attributes would be overkill and will be deployed elsewhere".

\section{Result for public sector bank}

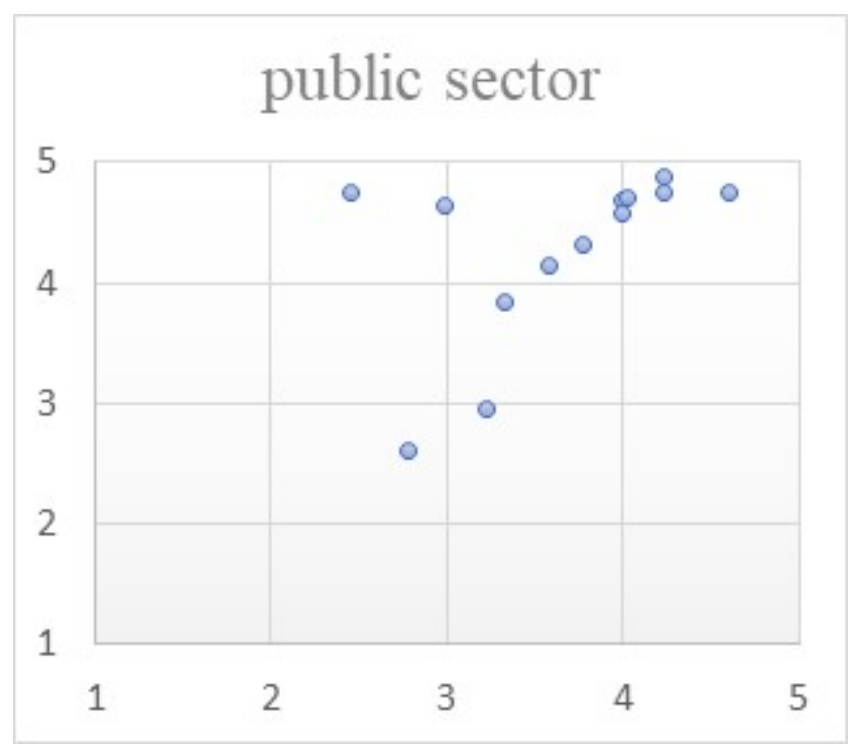

\begin{tabular}{|l|l|l|}
\hline \multicolumn{1}{|c|}{ Factors } & Satisfaction mean score & Expectation mean score \\
\hline All time availability & 4.225 & 4.875 \\
\hline Ease of use & 2.45 & 4.75 \\
\hline Confidentiality & 4.00 & 4.68 \\
\hline Security & 2.98 & 4.65 \\
\hline Social status & 3.23 & 2.95 \\
\hline Transparency & 3.325 & 3.85 \\
\hline Cost saving & 4.00 & 4.58 \\
\hline Time saving & 4.60 & 4.75 \\
\hline Accuracy & 3.78 & 4.33 \\
\hline Speed & 4.23 & 4.75 \\
\hline Service quality & 4.025 & 4.7 \\
\hline Nearby access & 3.58 & 4.15 \\
\hline Promotional offers & 2.78 & 2.60 \\
\hline
\end{tabular}

In public sector bank, ease of use and security (factors) are comes under quadrant $\mathrm{A}$. In quadrant $\mathrm{A}$, the factors comes under this concentrated by bank because the customer have high expectation but low satisfaction, the promotional offers (factor) comes under quadrant $\mathrm{C}$ were the customer gives low priority so the bank need not give importance to this 
factor, the transparency (factor)which is comes under quadrant D were the customer have low expectation but highly satisfied so the bank need not invest or promote the factor comes under this quadrant which need bank into "possible over kill" and all other factors(all time availability, confidentiality, cost saving, accuracy, speed, service quality and nearby access) comes under quadrant $\mathrm{B}$ were the customer have high expectation and high satisfaction so the bank should maintain the good services.

\section{Result for private sector bank}

\begin{tabular}{|l|l|l|}
\hline \multicolumn{1}{|c|}{ Factors } & \multicolumn{1}{|c|}{$\begin{array}{c}\text { Satisfaction } \\
\text { mean score }\end{array}$} & \multicolumn{1}{|c|}{$\begin{array}{c}\text { Expectation } \\
\text { mean score }\end{array}$} \\
\hline All time availability & 3.85 & 4.8 \\
\hline Ease of use & 2.40 & 4.53 \\
\hline Confidentiality & 4.25 & 4.53 \\
\hline Security & 3.93 & 4.28 \\
\hline Social status & 3.5 & 2.9 \\
\hline Transparency & 3.73 & 2.80 \\
\hline Cost saving & 3.95 & 4.43 \\
\hline Time saving & 4.73 & 4.75 \\
\hline Accuracy & 4.00 & 4.08 \\
\hline Speed & 4.55 & 4.725 \\
\hline Service quality & 4.20 & 4.50 \\
\hline Nearby access & 3.43 & 3.95 \\
\hline Promotional offers & 3.30 & 3.00 \\
\hline
\end{tabular}

In private sector bank, ease of use (factor) are comes under quadrant A. In quadrant A, the factors comes under this concentrated by bank because the customer have high expectation but low satisfaction, the promotional offers and social status (factor)which is comes under quadrant $\mathrm{D}$ were the customer have low expectation but highly satisfied so the bank need not invest or promote the factor comes under this quadrant which need bank into "possible over kill" and all other factors(all time availability, confidentiality, cost saving, accuracy, speed, service quality, security, transparency and nearby access) comes under quadrant B were the customer have high expectation and high satisfaction so the bank should maintain the good services. There is no factor in quadrant $\mathrm{C}$. 


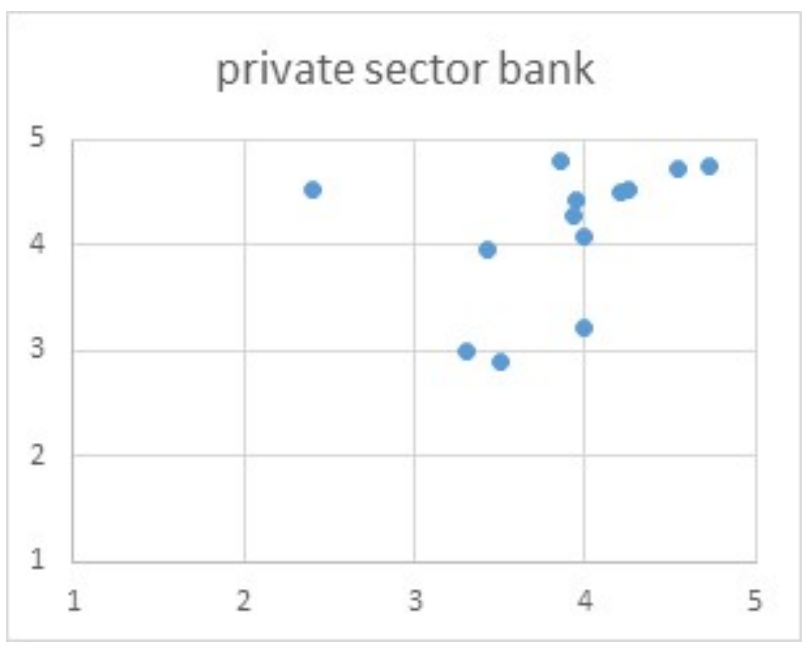

Table 3: To examine the problem faced by the respondents in E-banking services

\begin{tabular}{|l|l|l|l|l|}
\hline \multirow{2}{*}{\multicolumn{1}{c}{ Problems }} & \multicolumn{2}{c|}{ Public sector bank } & \multicolumn{2}{c|}{ Private sector bank } \\
\cline { 2 - 5 } & \multicolumn{1}{c|}{ Garrett score } & \multicolumn{1}{c|}{ Rank } & \multicolumn{1}{c|}{ Garrett score } & Rank \\
\hline Time consuming & 18.1875 & 7 & 17.0125 & 7 \\
\hline Security issue & 19.65 & 5 & 22.0375 & 5 \\
\hline ATM out of order & 30.4 & 2 & 18.8625 & 6 \\
\hline Amount debited but not withdraw & 35.1875 & 1 & 32.5625 & 1 \\
\hline Internet connectivity issue & 26.2875 & 3 & 24.6375 & 2 \\
\hline Password forgotten & 26.1 & 4 & 24.575 & 3 \\
\hline Card misplaced/misused & 19.1875 & 6 & 23.4625 & 4 \\
\hline
\end{tabular}

From the above table, in both public sector and private sector banks amount debited but not withdraw is a first problem faced by the sample respondent in e-banking services. This problem is creating more impact to customer in all ebanking service such as debit card, mobile banking and internet banking

\section{SUGGESTION AND CONCLUSIONS}

Based on survey and analysis my suggestion and conclusion are quick process to problems such as amount debited but not withdraw, server problem, proper disposal of funds in ATM and adding beneficiary to our account. Customers are not satisfied with ease of use so that be improved by adding local language to mobile and internet banking and adopting simple way for transaction. Most of customer need awareness about all E-banking services and bank must have proper security to customer and bank must reduce the transaction cost

\section{REFERENCES}

1. Martilla, J. A., \& James, J. C. (1977). Importance-performance analysis. Journal of marketing, 41(1), 77-79.

2. Lipkin, E., Mosig, M. O., Darvasi, A., Ezra, E., Shalom, A., Friedmann, A., \& Soller, M. (1998). Quantitative trait locus mapping in dairy cattle by means of selective milk DNA pooling using dinucleotide microsatellite markers: analysis of milk protein percentage. Genetics, 149(3), 1557-1567.

3. Dhamija, Ankita, and Diksha Sahni. "Green Banking: Perception and Willingness of Customers to Adapt Green Banking." International Journal of Financial Management 7.2 (2018): 1-8. 
4. Sohail, M. S., \& Shanmugham, B. (2003). E-banking and customer preferences in Malaysia: An empirical investigation. Information sciences, 150(3-4), 207-217.

5. Nupur, J. M. (2010). E-banking and customers' satisfaction in Bangladesh: An analysis. International review of business research papers, 6(4), 145-156.

6. SUDHARSHAN, BS. "A STUDY ON GROWTH OF RETAIL BANKING AND ITS BENEFITS TO BANKS IN INDIA." International Journal of Economics, Commerce and Research (IJECR) 9.2, Dec 2019, 23-28

7. Ahmad, A. E. M. K., \& Al-Zu'bi, H. A. (2011). E-banking functionality and outcomes of customer satisfaction: an empirical investigation. International journal of marketing studies, 3(1), 50-65.

8. ALHOSANI, FATIMA ABDULAZIZ, and MUHAMMAD USMAN TARIQ. "Improving Service quality of smart banking using quality management methods in UAE." International Journal of Mechanical Production Engineering Research and Development (IJMPERD) 10.3 (2020): 2249-8001.

9. Singh, Raghuvir, and VIJENDRA SINGH. "Issues and challenges of mobile banking application in Rajasthan." International Journal of Human Resource Management and research 7.2 (2017). 